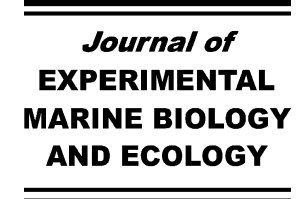

Journal of Experimental Marine Biology and Ecology 341 (2007) 254-263

www.elsevier.com/locate/jembe

\title{
Salinities, not diets, affect strontium/calcium ratios in otoliths of Anguilla japonica
}

\author{
Shih-Huan Lin ${ }^{\text {a }}$, Chih-Wei Chang ${ }^{\text {a }}$, Yoshiyuki Iizuka ${ }^{b}$, Wann-Nian Tzeng ${ }^{a, *}$ \\ a Institute of Fisheries Science, College of Life Science, National Taiwan University, Taipei, Taiwan, ROC \\ ${ }^{\mathrm{b}}$ Institute of Earth Sciences, Academia Sinica, Nankang, Taipei, Taiwan, ROC
}

Received 29 July 2006; received in revised form 23 October 2006; accepted 23 October 2006

\begin{abstract}
Although otolith Strontium (Sr)/calcium (Ca) ratios have been widely used to reconstruct the past salinity environmental history of anguillid eels, factors affecting the $\mathrm{Sr} / \mathrm{Ca}$ ratios in otoliths are incompletely understood. Japanese Eel (Anguilla japonica) elvers (mean length $54.7 \pm 2.1 \mathrm{~mm}$ ) were collected in the estuary during their upstream migration and reared at 5 different salinities $(0,5$, 15,25 , and $35 \mathrm{psu}$ ) and 3 types of feeding conditions (formulated feed, tubifex, and starvation) for 30 days to evaluate the effects of salinity and diets on otolith $\mathrm{Sr} / \mathrm{Ca}$ ratios. $\mathrm{Ca}$ and $\mathrm{Sr}$ concentrations in the ambient water significantly increased with salinity (SAL) as $[\mathrm{Ca}]_{\text {water }}=15.50 \mathrm{SAL}-5.56$, and $[\mathrm{Sr}]_{\text {water }}=0.21 \mathrm{SAL}+0.03$, respectively. $\mathrm{Sr} / \mathrm{Ca}$ ratios in otoliths increased with salinity $(\mathrm{SAL})$ of the rearing water as $[(\mathrm{Sr} / \mathrm{Ca}) \times 1000]$ otolith $=0.091 \mathrm{SAL}+3.790$. In diets, $\mathrm{Sr} / \mathrm{Ca}$ ratios were 4 times higher in tubifex than in formulated feed. However, in otoliths, ANOVA indicated that $\mathrm{Sr} / \mathrm{Ca}$ ratios did not differ significantly between groups fed on tubifex or formulated feed $(p=0.118)$. Otolith $\mathrm{Sr} / \mathrm{Ca}$ ratios were negatively correlated with fish growth rates while the growth rates differed significantly among rearing conditions with different salinities and diets. Partition coefficients of the $\mathrm{Sr} / \mathrm{Ca}$ ratios from ambient water to fish tissues and otoliths significantly increased with salinity. The $\mathrm{Sr} / \mathrm{Ca}$ ratios of Japanese Eel otoliths thus were positively correlated with the ambient salinity and decreased with increasing fish growth rate, but was not affected by fish diet. (C) 2006 Elsevier B.V. All rights reserved.
\end{abstract}

Keywords: Anguilla japonica; Diets; Growth rate; Otolith; Partition coefficients; Sr/Ca ratios

\section{Introduction}

Otoliths function for hearing and balance in teleost fishes. They are composed of calcium carbonate and a small amount of organic matter that is deposited rhythmically as aragonite crystals within a protein matrix (Degens et al., 1969; Gauldie and Nelson, 1988). Thirtyone elements have been detected in otoliths, not including

\footnotetext{
* Corresponding author. Life Sciences Building, 622R, No.1, Sec. 4, Roosevelt Road, Taipei, Taiwan 106. Tel.: +886 2 33662887; fax: +886223639570.

E-mail address: wnt@ccms.ntu.edu.tw (W.-N. Tzeng).
}

radioactive elements such as Th and $\mathrm{Ra}$ (Campana, 1999). The elemental composition of otoliths may reflect that of the surrounding water (Campana, 1999; Milton and Chenery, 2001). Trace elements such as strontium (Sr), are approximately two orders of magnitude higher in seawater than in freshwater and otolith $\mathrm{Sr} / \mathrm{Ca}$ ratios differ between fish living in seawater and freshwater (Secor and Rooker, 2000). Thus, $\mathrm{Sr} / \mathrm{Ca}$ ratios in otoliths have been widely used for reconstructing the environmental history of diadromous fish migration between marine and fresh waters.

Japanese Eel, Anguilla japonica, are catadromous fishes, spawning in waters west of the Mariana Islands 
(Tsukamoto, 1992; Liao et al., 1996, 1999). The North Equatorial and Kuroshio currents transport the leptocephalus larvae over 4-6 months from the spawning ground to the continental shelf of the Asian countries, Taiwan, China, Korea and Japan (Cheng and Tzeng, 1996). They then metamorphose to glass eels before entering coastal waters where they become pigmented elvers in the estuaries. Most of the elvers migrate upstream to the river and grow to become yellow eels. At maturation, yellow eels become silver eels and migrate downstream to spawn and die. However, recent studies have indicated that part of an eel population may skip the freshwater phase and complete their life cycle in seawater (Tzeng and Tsai, 1994; Tsukamoto et al., 1998; Tzeng et al., 2000, 2002; Tsukamoto and Arai, 2001; Jessop et al., 2002; Tzeng, 2003; Cairns et al., 2004; Kotake et al., 2004; Daverat et al., 2006). This inference is based on the correlation between the level of $\mathrm{Sr} / \mathrm{Ca}$ ratios in eel otoliths and salinity (Tzeng, 1996; Kawakami et al., 1998). Similar phenomena were also found in salmonids (Kalish, 1990), Inconnu, Stenodus leucichthys, (Howland et al., 2001), Baltic Sea Trout, Salmo trutta, (Limburg et al., 2001), Striped Bass, Morone saxatilis, (Secor and Piccoli, 1996), and Stream Goby (Radtke and Kinzie, 1996; Shen et al., 1998; Shen and Tzeng, 2002).

The incorporation of strontium and calcium into the otolith is a complex biogeochemical process. Elements in the ambient water enter the fish body by absorption through the gills and digestive system. Thus, water chemistry, salinity, and diet may all potentially influence the otolith $\mathrm{Sr} / \mathrm{Ca}$ ratio. Otolith $\mathrm{Sr} / \mathrm{Ca}$ ratios were influenced by both salinity and diet for species such as Cutthroat Trout, Oncorhynchus clarkii (Farag et al., 2000), Mud Skipper, Periophthalmus cantonensis, and Glass Fishes, Ambassis urotaenia (Ni et al., 2000), American Shad, Alosa sapidissima (Limburg, 1995), Tilapia, Oreochromis niloticus (Farrell and Campana, 1996), Gicella elevate (Gallahar and Kingsford, 1996) and Bluefish, Pomatomus saltatrix (Buckel et al., 2004). However, the $\mathrm{Sr} / \mathrm{Ca}$ ratios in the otoliths of Red Drum, Sciaenops ocellatus, were not affected by diet (Hoff and Fuiman, 1995). This indicated that the effect of diets on otolith $\mathrm{Sr} / \mathrm{Ca}$ ratio is species-specific. Walther and Thorrold (2006) also found that water, not food, was the major contributor of $\mathrm{Sr}$ for marine fishes. They also suggested the relative importance of water and dietary sources to the otolith may change depending on $\mathrm{Ca}$ availability in the water column. Because $\mathrm{Ca}$ concentration varies with salinity, freshwater fishes may compensate for decreased water-Ca by deriving relatively more ion from their food. It is important to clarify the effects of salinity and diets on otolith $\mathrm{Sr} / \mathrm{Ca}$ ratios before it is used to study the migratory environmental history of eels.

The incorporation of element from the environment into the otoliths is a multi-stage process and is characterized by a sequence of more or less independent barriers. Elements pass by ion transport from blood plasma into the endolymph and are finally precipitated on to the otolith surface (Campana, 1999). The partition coefficients for elements transported from the ambient environment to otolith differ across different barriers. In most otolith studies, the partition coefficients of otolith elements were directly related to the ambient water because of difficulties in measuring concentrations in the endolymphatic fluid surrounding the otolith (Bath et al., 2000; Milton and Chenery, 2001; Kraus and Secor, 2004). The partition coefficient of $\mathrm{Sr} / \mathrm{Ca}$ ratios from ambient water to otolith for the Japanese Eel, however, is still unclear.

In this study we examined the effects of salinity and diet on the incorporation of strontium and calcium, and the resultant $\mathrm{Sr} / \mathrm{Ca}$ ratio, into the otoliths of the Japanese Eel. The partition coefficients for the $\mathrm{Sr} / \mathrm{Ca}$ ratio $\left(D_{\mathrm{Sr}}\right)$ between the ambient water and fish tissue and otolith were compared among diets to further understand the uptake of $\mathrm{Sr} / \mathrm{Ca}$ ratio for the eel in different salinities.

\section{Materials and methods}

\subsection{Experimental design}

Japanese Eel elvers were collected from Gong-ShyTyan Creek in the northwestern Taiwan in March 2002. The mean total length of the elvers was $54.7 \pm 2.1 \mathrm{~mm}$ (mean $\pm \mathrm{SD})$. After acclimation in brackish water at salinity of $10 \mathrm{psu}$ for one month, elvers were immersed in 50 ppm Alizarin Complexone (ALC, Sigma A-3882) solution for $6 \mathrm{~h}$ to produce a fluorescent mark in the otolith to identify the onset of the experiment. Two replicates were then reared for 30 days at a mean room temperature of $22.8 \pm 0.5^{\circ} \mathrm{C}$ (range $16.4{ }^{\circ} \mathrm{C}-30.0^{\circ} \mathrm{C}$ ) in different conditions consisting of 5 different salinity conditions $(0,5,15,25$ and $35 \mathrm{psu})$ and 3 different feeding conditions (formulated feed, turbifex and starvation). Each aquarium contained 101 of rearing water at a stocking density of approximately one elver per liter. The brackish rearing water was prepared by mixing in measured proportions of with freshwater from the Feitsui Reservoir in northern Taiwan and seawater from offshore in northern Taiwan. The eels were fed once daily and unconsumed food was removed during acclimatation including starved eels. The rearing water 
Table 1

Homogeneity test by Tukey's honest significant difference (HSD) test for the mean $( \pm \mathrm{SD})$ total length of the fish reared with different feeds (A) and salinities (B)

\begin{tabular}{lclll}
\hline & \multirow{2}{*}{$\begin{array}{l}\text { Sample } \\
\text { size }\end{array}$} & \multicolumn{2}{l}{ Total length $(\mathrm{mm})$} & HG \\
\cline { 3 - 4 } & & Range & Mean \pm SD & \\
\hline A. Feeds & & & & \\
Tubifex & 69 & $54.69-82.80$ & $69.60 \pm 6.36$ & $\mathrm{a}$ \\
Eel feed & 47 & $51.54-81.21$ & $61.20 \pm 6.83$ & $\mathrm{~b}$ \\
Starvation & 49 & $52.38-61.12$ & $56.52 \pm 2.47$ & $\mathrm{c}$ \\
& & & & \\
B. Salinity $(p s u)$ & & & & \\
0 & 42 & $51.54-82.80$ & $64.47 \pm 9.01$ & $\mathrm{a} \mathrm{b}$ \\
5 & 50 & $52.21-81.58$ & $63.47 \pm 7.69$ & $\mathrm{a} \mathrm{b}$ \\
15 & 45 & $52.38-81.21$ & $63.22 \pm 7.79$ & $\mathrm{a} \mathrm{b}$ \\
25 & 5 & $61.12-73.61$ & $66.46 \pm 4.76$ & $\mathrm{a}$ \\
35 & 23 & $53.94-77.51$ & $60.39 \pm 7.04$ & $\mathrm{~b}$ \\
\hline
\end{tabular}

The same letters between feeds and salinities indicate that they are the same homogeneous group (HG). Different sample sizes were due to different survival rates.

salinity was monitored daily by salinometer (WTW Cond $333 i$ ) and $10 \%$ of the water was changed every 3 days.

\subsection{Measurement of $\mathrm{Sr}$ and Ca levels in the water, diet, fish tissue, and otolith}

At the end of the experiment, the eels were sacrificed and fixed in $95 \%$ alcohol. The total length (to $0.01 \mathrm{~mm}$ ) and body weight (to $0.01 \mathrm{~g}$ ) of eels were measured. The rearing water was filtered by a $0.45 \mu \mathrm{m}$ filter and diluted by deionized water before measuring the $\mathrm{Ca}$ and $\mathrm{Sr}$

Table 2

Homogeneity test by Tukey's honest significant difference (HSD) test for the mean $( \pm \mathrm{SD})$ body weight of the fish reared with different feeds (A) and salinities (B)

\begin{tabular}{lclll}
\hline & $\begin{array}{l}\text { Sample } \\
\text { size }\end{array}$ & \multicolumn{2}{l}{ Body weight $(\mathrm{g})$} & HG \\
\cline { 3 - 4 } & & Range & Mean \pm SD & \\
\hline A. Feeds & 69 & $0.072-0.415$ & $0.219 \pm 0.074$ & $\mathrm{a}$ \\
Tubifex & 47 & $0.035-0.378$ & $0.126 \pm 0.085$ & $\mathrm{~b}$ \\
Eel feed & 49 & $0.028-0.072$ & $0.044 \pm 0.011$ & $\mathrm{c}$ \\
Starvation & 49 & & & \\
& & & & \\
B. Salinity $(p s u)$ & & & & \\
0 & 42 & $0.030-0.415$ & $0.169 \pm 0.106$ & $\mathrm{a}$ \\
5 & 50 & $0.029-0.374$ & $0.132 \pm 0.091$ & $\mathrm{a} \mathrm{b}$ \\
15 & 45 & $0.028-0.378$ & $0.141 \pm 0.103$ & $\mathrm{a} \mathrm{b}$ \\
25 & 5 & $0.042-0.236$ & $0.155 \pm 0.078$ & $\mathrm{a} \mathrm{b}$ \\
35 & 23 & $0.032-0.339$ & $0.101 \pm 0.087$ & $\mathrm{~b}$ \\
\hline
\end{tabular}

The same letters between feeds and salinities indicate that they are the same homogeneous group (HG). Different sample sizes were due to different survival rates. (a)

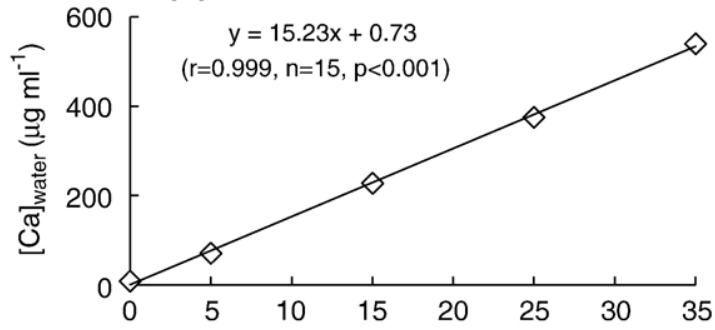

(b)
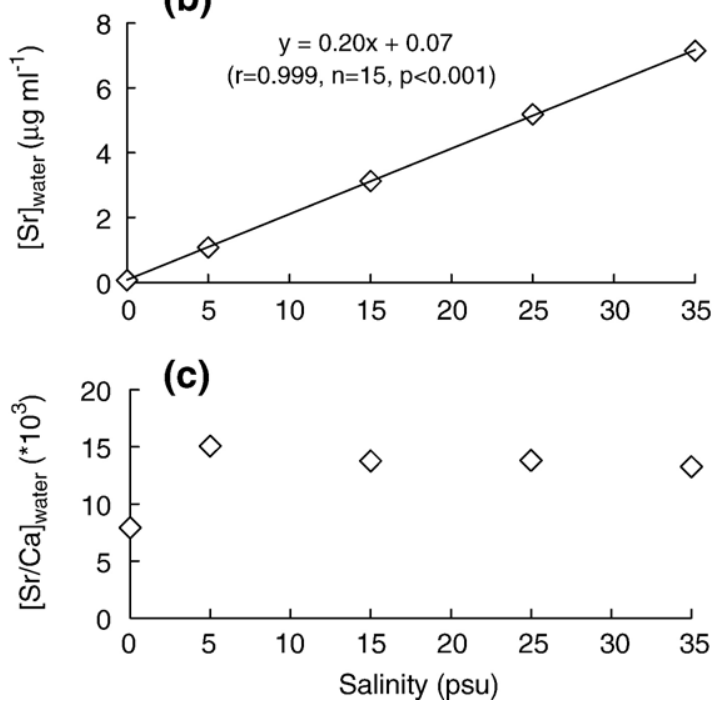

Fig. 1. The relationship between $\mathrm{Ca}$ (a) and $\mathrm{Sr}$ (b) content, and $\mathrm{Sr} / \mathrm{Ca}$ concentration ratio (c) and salinity, with tests of the significance of the difference in $\mathrm{Ca}, \mathrm{Sr}$ and $\mathrm{Sr} / \mathrm{Ca}$ ratio among groups of different salinity.

concentration. Diet and fish tissue samples (whole elver minus otoliths) were dried at $60{ }^{\circ} \mathrm{C}$ for $48 \mathrm{~h}$ and weighed. After weighing, they were digested with high purity nitric acid, filtered by $0.45 \mu \mathrm{m}$ filter, and diluted by deionized water (Chang et al., 2004). Then the $\mathrm{Sr}$ and $\mathrm{Ca}$ concentrations in water, diet, and fish tissue samples were measured by atomic absorption spectrophotometer (AAS, Hitachi Z-5000) using the air-acetylene flame protocol.

Otoliths were removed under stereomicroscope (SMZ-10, Nikon) after one week from fish fixed in 95\% alcohol. The otoliths were cleaned ultrasonically, embedded in Epofix (Struers), cut by Isomet low speed saw (Buehler), and polished by Metaserv grinderpolisher (Buehler) until the primordium was revealed. They were then dried at $60^{\circ} \mathrm{C}$ for $48 \mathrm{~h}$, and coated with carbon for the measurement of otolith $\mathrm{Sr}$ and $\mathrm{Ca}$ content using an electron probe micro-analyzer equipped with wavelength dispersive $\mathrm{x}$-ray spectrometers (JEOL EPMA; JXA-8900R). The EPMA beam conditions for the analysis were set as: an accelerating voltage of 
Table 3

Homogeneity test by Tukey's honest significant difference (HSD) test for the mean $( \pm \mathrm{SD}) \mathrm{Sr} / \mathrm{Ca}$ ratios of different diets

\begin{tabular}{lllll}
\hline Diet & $\begin{array}{l}\text { Sample } \\
\text { size }\end{array}$ & & & HG \\
\cline { 3 - 4 } & & Mean $/ \mathrm{Ca}) \times 10^{3}$ & $\mathrm{SD}$ & \\
\hline Tubifex & 27 & 4.71 & 0.48 & $\mathrm{a}$ \\
Eel feed & 27 & 1.12 & 0.02 & $\mathrm{~b}$ \\
\hline
\end{tabular}

The same letters between diets indicate that they do not significantly differ (HG).

$15 \mathrm{KV}$, an accelerating current of $3 \mathrm{nA}$, and a beam size with a rectangular area of $5 \times 4 \mu \mathrm{m}$. Synthetic aragonite $\left(\mathrm{CaCO}_{3}\right)$ and strontianite $\left(\mathrm{SrCO}_{3} ; \mathrm{NMNH} \mathrm{R} 10065\right)$ were used as standards for calibrating the $\mathrm{Ca}$ and $\mathrm{Sr}$ contents in the otoliths. The quantitative data were corrected by the $Z A F$ method ( $Z$, atomic number; $A$, absorption; and $F$, fluorescence correction). Otolith $\mathrm{Sr}$ and $\mathrm{Ca}$ contents (wt.\%) were measured from the core to the edge along the longest axis, and from fluorescent marks to the otolith edge was the experimental period to determine the effects of salinity, diet, and growth rate on the otolith $\mathrm{Sr} / \mathrm{Ca}$ ratios.

\subsection{Data analysis}

The effects of rearing conditions on eel survival and growth rate and the $\mathrm{Sr} / \mathrm{Ca}$ ratio in fish tissue and otolith were examined by analysis of variance (ANOVA) and Tukey's honest significant difference (HSD) (Arslan and Secor, 2005; Jessop et al., 2004). We supposed the eels have the same total length and body weight before

Table 4

Homogeneity test by Tukey's honest significant difference (HSD) test for the mean $( \pm \mathrm{SD}) \mathrm{Sr} / \mathrm{Ca}$ ratios in the tissue of fish reared with different diets (A) and salinity (B)

\begin{tabular}{lllll}
\hline & $\begin{array}{l}\text { Sample } \\
\text { size }\end{array}$ & \multicolumn{2}{l}{$(\mathrm{Sr} / \mathrm{Ca}) \times 10^{3}$} & HG \\
\cline { 3 - 4 } & & Range & Mean $\pm \mathrm{SD}$ & \\
\hline A. Diet & & & & \\
Tubifex & 30 & $2.36-5.23$ & $3.84 \pm 0.75$ & $\mathrm{a}$ \\
Starvation & 30 & $3.23-4.89$ & $4.07 \pm 0.42$ & $\mathrm{a}$ b \\
Eel feed & 60 & $1.76-6.78$ & $4.26 \pm 1.02$ & $\mathrm{~b}$ \\
& & & & \\
B. Salinity (psu) & & & & \\
0 & 24 & $1.76-4.63$ & $3.12 \pm 0.68$ & $\mathrm{a}$ \\
5 & 24 & $3.28-5.01$ & $3.98 \pm 0.45$ & $\mathrm{~b}$ \\
15 & 24 & $3.30-5.39$ & $4.06 \pm 0.48$ & $\mathrm{~b}$ \\
25 & 24 & $3.49-6.78$ & $4.70 \pm 0.67$ & $\mathrm{c}$ \\
35 & 24 & $3.26-6.52$ & $4.67 \pm 0.80$ & $\mathrm{c}$ \\
\hline
\end{tabular}

The same letters between feeds and salinities indicate that they do not significantly differ (HG). (a)

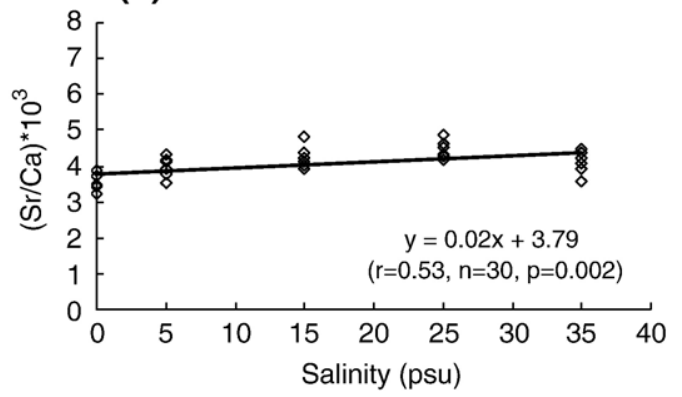

(b)

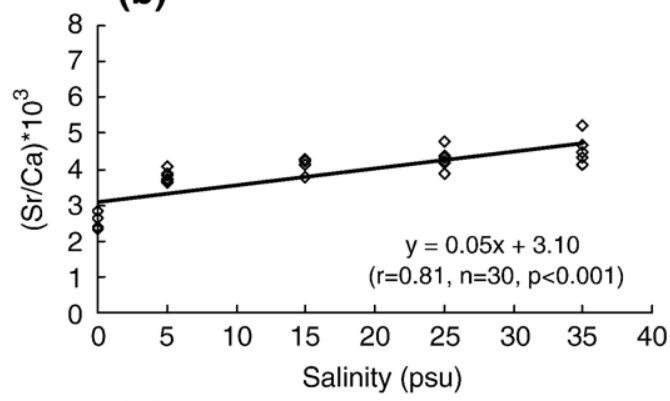

(c)

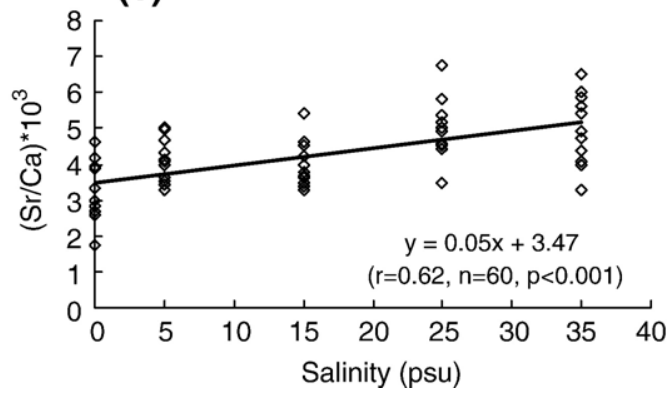

Fig. 2. Linear regressions of the $\mathrm{Sr} / \mathrm{Ca}$ ratio in fish tissue on salinity for the fish starvation (a), fed with tubifex (b), and fed with formulated eel feed (c).

experiment, so the growth rates were calculated by the total length and body weight of the eels after experiment. And because there was little growth from the ALC mark to edge of the otoliths of Starvation group, $\mathrm{Sr} / \mathrm{Ca}$ ratios of this group were not analyzed. The partition coefficients of the $\mathrm{Sr} / \mathrm{Ca}$ ratio $\left(D_{\mathrm{Sr}}\right)$ among ambient water, fish tissue, and otolith were calculated by:

$D_{\mathrm{Sr}}=[\mathrm{Sr} / \mathrm{Ca}]_{\text {fish tissues, otoliths }} /[\mathrm{Sr} / \mathrm{Ca}]_{\text {water }}$

Significant differences in slope and adjusted mean of the regressions of $D_{\mathrm{Sr}}$ on salinity among rearing conditions were examined by analysis of covariance (ANCOVA). 


\section{Results}

\subsection{Effects of diets and salinities on fish survival and growth rate}

Eel survival rates did not differ significantly among salinities $(p>0.05)$. In Tables 1 and 2 mentioned about the growth, we only measured the eels which were still alive at the end. This is why we had different sample sizes.

The mean total lengths and weights of the eels differed significantly among feeding conditions at the end of the experiment. Eels fed with tubifex grew the fastest, followed by those fed formula, and the starvation group was the slowest (Tables 1a and 2a). The optimal salinity for eel growth was 25 psu for length $(p<0.01)$ and 0 psu for weight $(p<0.01)$ in the eels with feeding. The slowest growth rate for both length and weight was 35 psu (Tables $1 b$ and $2 b$ ).

\section{2. $\mathrm{Sr}$ and $\mathrm{Ca}$ concentration and $\mathrm{Sr} / \mathrm{Ca}$ ratio in the} rearing water and its relation to salinity

Both $\mathrm{Sr}$ and $\mathrm{Ca}$ concentrations in the rearing water were differed significantly among the 5 experimental salinities $(0-35 \mathrm{psu})(p<0.001)$, and were significantly increased with salinity (SAL). Linear regressions for the relations were: $[\mathrm{Ca}]_{\text {water }}=15.50 \mathrm{SAL}-5.56$, and $[\mathrm{Sr}]_{\text {water }}=0.21 \mathrm{SAL}+0.03$ (Fig. 1a,b).

The difference in $\mathrm{Sr} / \mathrm{Ca}$ concentration ratio among the 5 salinities could be divided into two groups, with the ratio increasing approximately 2-fold from $7.91 \pm$

Table 5

Tukey's honest significant difference (HSD) test for the difference in mean $( \pm \mathrm{SD}) \mathrm{Sr} / \mathrm{Ca}$ ratios in otolith of the fish reared with different diets (A) and salinity (B)

\begin{tabular}{lclll}
\hline & $\begin{array}{l}\text { Sample } \\
\text { size }\end{array}$ & \multicolumn{2}{l}{$(\mathrm{Sr} / \mathrm{Ca}) \times 10^{3}$} & HG \\
\cline { 3 - 4 } & & Range & Mean $\pm \mathrm{SD}$ & \\
\hline A. Diet & 348 & $1.03-9.88$ & $5.27 \pm 1.74$ & $\mathrm{a}$ \\
Tubifex & 439 & $0.60-9.34$ & $4.80 \pm 1.69$ & $\mathrm{a}$ \\
Eel feed & & & & \\
B. Salinity $(p s u)$ & & & \\
0 & 249 & $0.60-6.91$ & $3.13 \pm 1.12$ & $\mathrm{a}$ \\
5 & 148 & $1.81-6.81$ & $5.14 \pm 0.86$ & $\mathrm{~b}$ \\
15 & 163 & $3.64-7.86$ & $5.66 \pm 0.97$ & $\mathrm{c}$ \\
25 & 60 & $3.81-8.04$ & $6.22 \pm 0.86$ & $\mathrm{~d}$ \\
35 & 167 & $3.80-9.88$ & $6.61 \pm 1.25$ & $\mathrm{e}$ \\
\hline
\end{tabular}

The same letters between feeds and salinities indicate that they are the same homogeneous group (HG). Different sample sizes were due to every otolith has different widths for analysis, so the sample sizes were not coincidence.

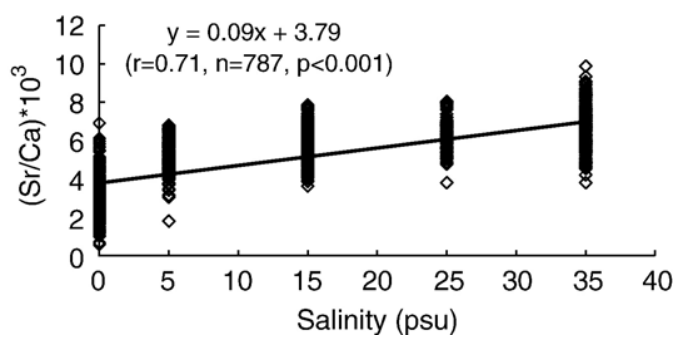

Fig. 3. The relationship between otolith $\mathrm{Sr} / \mathrm{Ca}$ ratio and salinity fitted by linear regression.

$0.41 \times 10^{-3}$ in the freshwater group to $15.07 \pm$ $0.63 \times 10^{-3}$ in the salinity group ranging from 5$35 \mathrm{psu}$ (Fig. 1c). This indicates that the $\mathrm{Sr} / \mathrm{Ca}$ ratio differ between freshwater and seawater and are constant irrespective of the seawater salinities.

(a)

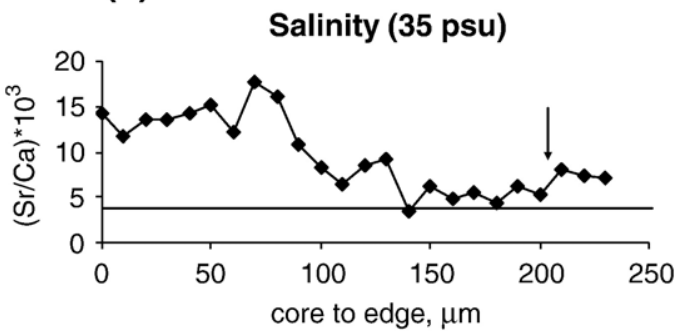

(b)

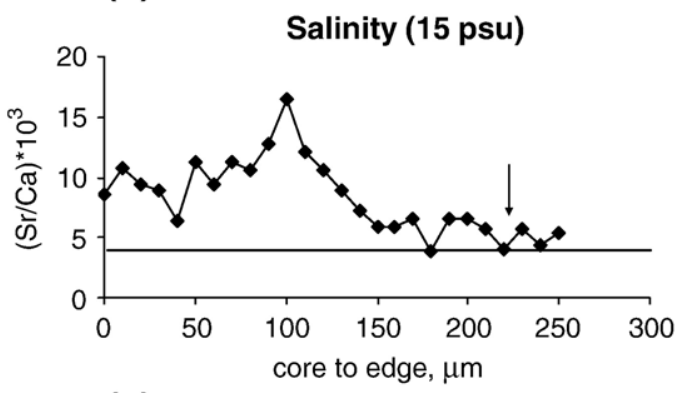

(c)

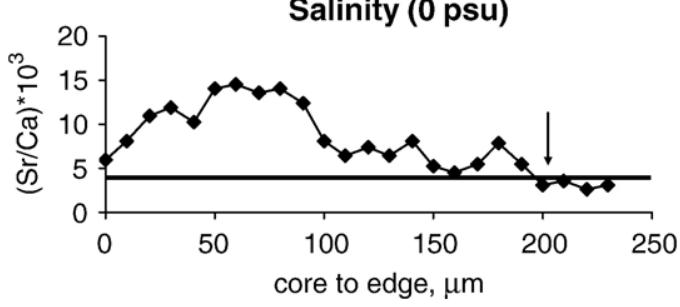

Fig. 4. $\mathrm{Sr} / \mathrm{Ca}$ ratios measured from the core to otolith edge along the longest axis for three salinity conditions (a) salinity 35\% (seawater) (b) salinity $15 \%$ (brackish water) and (c) salinity $0 \%$ (freshwater); Horizontal line: salinity boundary, arrow: TC mark. (the Sr:Ca peak caused by the leptocephalus metamorphosis). 


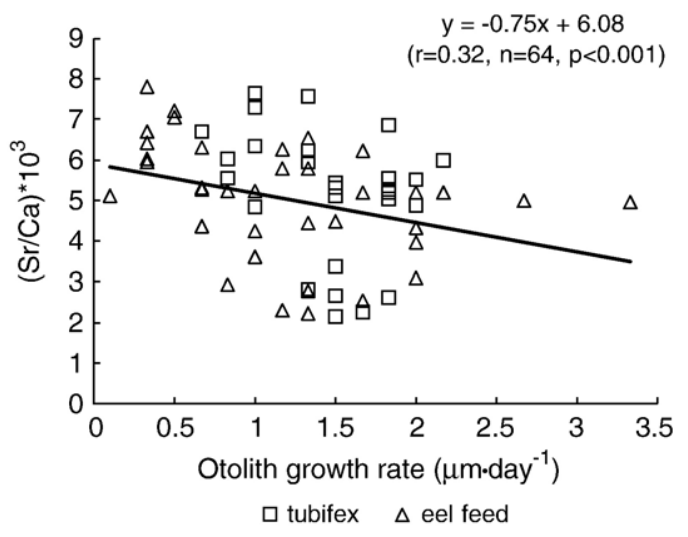

Fig. 5. The relationship between otolith $\mathrm{Sr} / \mathrm{Ca}$ ratio and otolith daily growth rate.

\subsection{Comparison of food Sr:Ca ratio between diets}

The $\mathrm{Sr} / \mathrm{Ca}$ ratio differed significantly between the two diets (ANOVA, $p<0.05$ ) (Table 3). The ratios were approximately 4 times higher in tubifex than in eel feed.

\subsection{Effects of diet and salinity on $\mathrm{Sr} / \mathrm{Ca}$ ratio in fish tissues}

The $\mathrm{Sr} / \mathrm{Ca}$ ratios in tissues varied significantly with diet and salinity (Table 4). The $\mathrm{Sr} / \mathrm{Ca}$ ratios in tissues were higher in the group fed with formulated eel feed than with tubifex (Table $4 \mathrm{a}$ ). $\mathrm{The} \mathrm{Sr} / \mathrm{Ca}$ ratio in the fish tissues were highest in those fish reared in salinities of $25 \mathrm{psu}$ and $35 \mathrm{psu}$, followed by 15 and $5 \mathrm{psu}$, with the lowest ratios in the group at 0 psu (Table 4b). All regressions of the $\mathrm{Sr} / \mathrm{Ca}$ ratio in fish tissues on salinities were significant for all feeding conditions $(p<0.002$ and 0.001) (Fig. 2a,b,c).

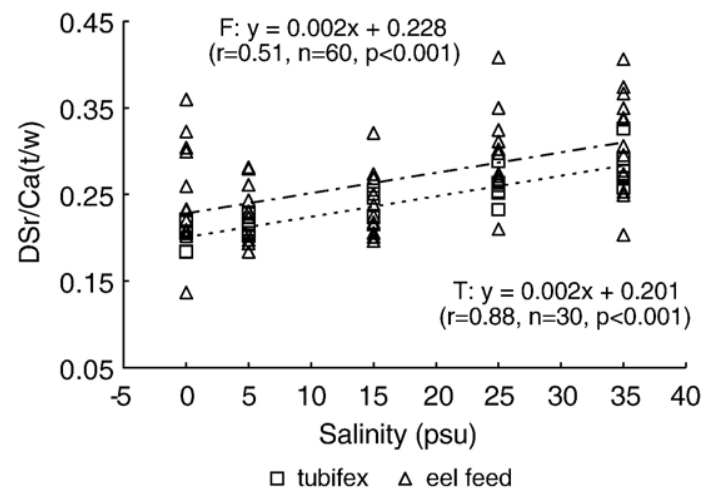

Fig. 6. The relationship between partition coefficients of the $\mathrm{Sr} / \mathrm{Ca}$ ratio between fish tissue and ambient water on salinity for fish fed with tubifex $(\mathrm{T})$ and formulated eel feed $(\mathrm{F})$.

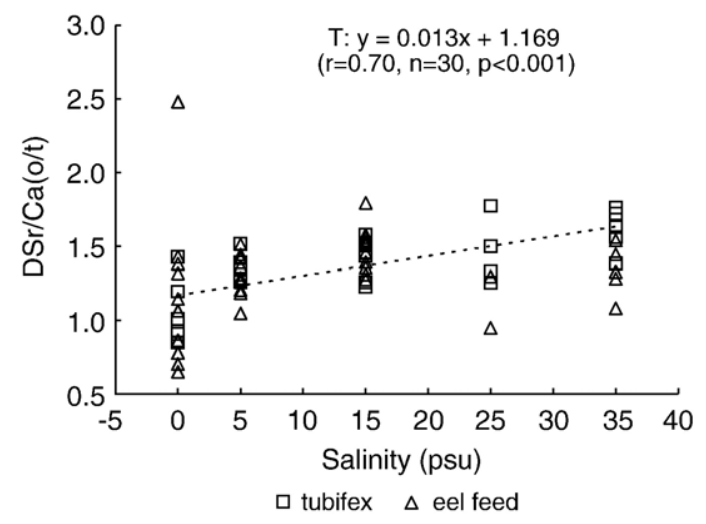

Fig. 7. The relationship between partition coefficients of the $\mathrm{Sr} / \mathrm{Ca}$ ratio between fish otolith and tissue on salinity for fish fed with tubifex (T) and formulated eel feed (F).

\subsection{Effect of diet and salinity on otolith $\mathrm{Sr} / \mathrm{Ca}$ ratio}

The otolith $\mathrm{Sr} / \mathrm{Ca}$ ratio did not differ significantly among the fish reared with different diets $(p>0.05)$ (Table 5a), but did differ significantly among those reared at different salinities $(p<0.01)$ (Table 5a). The mean $( \pm \mathrm{SD}) \mathrm{Sr} / \mathrm{Ca}$ ratio in otoliths significantly increased from $3.13 \pm 0.12$ in freshwater ( $0 \mathrm{psu})$ to $6.61 \pm 1.25$ in seawater (35 psu). The relationship between $\mathrm{Sr} / \mathrm{Ca}$ ratio in otoliths and salinity was significant related and fitted by linear regression (Fig. 3). Thus, the $\mathrm{Sr} / \mathrm{Ca}$ ratio in otoliths was affected by salinity irrespective of the $\mathrm{Sr} / \mathrm{Ca}$ ratio in water being constant over different salinities (5-35 psu) (Fig. 1c). To evaluate the measurement conditions, $\mathrm{Sr} / \mathrm{Ca}$ ratios before and during the experiment period from the core to the otolith edge along the longest axis were measured. The results before the experiment were quite consistent and stable (Fig. 4).

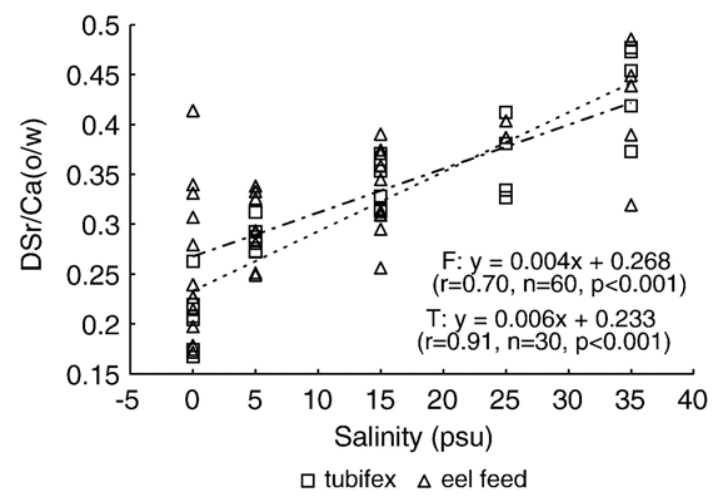

Fig. 8. The relationship between partition coefficients of the $\mathrm{Sr} / \mathrm{Ca}$ ratio between otolith and ambient water on salinity for fish fed with tubifex (T) and formulated eel feed (F). 


\subsection{Effect of growth rate on otolith $\mathrm{Sr} / \mathrm{Ca}$ ratio}

Mean $\mathrm{Sr} / \mathrm{Ca}$ ratio and mean increment widths beyond the ALC mark in the eel otoliths were negatively correlated irrespective of diet and no correlated with salinity $(r=0.32, p<0.001)$ (Fig. 5). This indicated that the $\mathrm{Sr} / \mathrm{Ca}$ concentration ratios in otoliths decreased with increasing fish growth rate, on the assumption that otolith growth is positively related to fish growth.

\subsection{Effects of diet and salinity on partition coefficients of $\mathrm{Sr} / \mathrm{Ca}$ ratio between barriers}

The regressions of the partition coefficients of $\mathrm{Sr} / \mathrm{Ca}$ ratio $\left(D_{\mathrm{Sr}}\right)$ on salinity between different barriers were calculated as follows:

(1) Regressions of $D_{\mathrm{Sr}}(\mathrm{t} / \mathrm{w})$ of $\mathrm{Sr} / \mathrm{Ca}$ ratio on salinity between ambient water and fish tissue for the fish fed with tubifex and formulated feed were calculated as follows (Fig. 6):

Tubifex $D_{\mathrm{Sr}}(\mathrm{t} / \mathrm{w})=0.0024 \mathrm{SAL}+0.2006(r=0.88$, $p<0.001)$;

Eel feed $D_{\mathrm{Sr}}(\mathrm{t} / \mathrm{w})=0.0023 \mathrm{SAL}+0.2282(r=0.51$, $p<0.001)$;

Starvation: the regression of $D_{\mathrm{Sr}}$ on salinity was not significant $(p>0.05)$ (data not shown).

(2) Regressions of $D_{\mathrm{Sr}}(\mathrm{o} / \mathrm{t})$ of $\mathrm{Sr} / \mathrm{Ca}$ ratio on salinity between fish tissue and otolith for the fish fed with tubifex and formulated feed were calculated as follows (Fig. 7):

Tubifex $D_{\mathrm{Sr}}(\mathrm{o} / \mathrm{t})=0.0132 \mathrm{SAL}+1.1686 \quad(r=0.70$, $p<0.001$ );

Eel feed the regressions of $D_{\mathrm{Sr}}$ on salinity were not significant $(p>0.05)$.

Starvation: slowly growth made the width between ALC mark and edges of the otolith not wide enough for analysis.

(3) Regressions of $D_{\mathrm{Sr}}(\mathrm{o} / \mathrm{w})$ of $\mathrm{Sr} / \mathrm{Ca}$ ratio on salinity between ambient water and otolith for the fish fed with tubifex and formulated feed were calculated as follows (Fig. 8):

Tubifex $D_{\mathrm{Sr}}(\mathrm{o} / \mathrm{w})=0.0065 \mathrm{SAL}+0.2332(r=0.91$, $p<0.001)$

Eel feed $D_{\mathrm{Sr}}(\mathrm{o} / \mathrm{w})=0.0044 \mathrm{SAL}+0.2676(r=0.70$, $p<0.001)$;

Starvation: slowly growth made the width between ALC mark and edges of the otolith not wide enough for analysis.
The partition coefficients of $\mathrm{Sr} / \mathrm{Ca}$ ratio among ambient water and fish tissue and otolith all increased with salinity and were not significantly different between diets $(p=0.24, p=0.78)$.

\section{Discussion}

\subsection{The response of otolith $\mathrm{Sr} / \mathrm{Ca}$ ratios to salinity}

The relationship between otolith $\mathrm{Sr} / \mathrm{Ca}$ ratio and ambient water salinity has been examined for many species, such as juvenile Striped Bass, M. saxatilis (Secor et al., 1995), Japanese Sea Bass, Lateolabrax japonicus (Secor et al., 1998), and Japanese Eels, A. japonica (Tzeng, 1996; Kawakami et al., 1998), but the response of otolith $\mathrm{Sr} / \mathrm{Ca}$ ratio to salinity is inconsistent among species. Tzeng (1996) established a linear regression of otolith $\mathrm{Sr} / \mathrm{Ca}$ ratio on salinity for Japanese Eel as: [ $(\mathrm{Sr} /$ Ca) $\times 1000]_{\text {otolith }}=0.14_{\mathrm{SAL}}+3.797$, which is similar to the results of this study: $[(\mathrm{Sr} / \mathrm{Ca}) \times 1000]_{\text {otolith }}=0.09 \mathrm{SAL}+$ 3.790 , particularly the regression intercept. Both regressions indicated that the $\mathrm{Sr} / \mathrm{Ca}$ ratio in otoliths increases with increasing salinity. However, Chang et al. (2004) conducted a similar experiment for the grey mullet, Mugil cephalus, using the same water source as in this study, and found that the regression of otolith $\mathrm{Sr} / \mathrm{Ca}$ ratio on salinity differed significantly between fish reared in fresh water (0 psu) and brackish water (5-35 psu) and that the otolith $\mathrm{Sr} / \mathrm{Ca}$ ratio did not increase with increasing salinity of the rearing water. Thus, the relationship between otolith $\mathrm{Sr} / \mathrm{Ca}$ ratio and salinity may be species-specific. In other words, the $\mathrm{Sr} / \mathrm{Ca}$ ratio in the otolith increased with salinity level for the Japanese Eel, but the $\mathrm{Sr} / \mathrm{Ca}$ ratio of grey mullet otoliths followed the $\mathrm{Sr} / \mathrm{Ca}$ ratio, not the salinity, of the rearing water (Fig. 1). The intercept of the regression of otolith $\mathrm{Sr} / \mathrm{Ca}$ ratio on salinity was at approximately 4 when the salinity was $0 \mathrm{psu}$ in both studies. The repeatability of the relationship between otolith $\mathrm{Sr} / \mathrm{Ca}$ ratio and salinity for the Japanese Eel suggests that using the otolith $\mathrm{Sr} / \mathrm{Ca}$ at 4 to discriminate the habitat use of the eels between freshwater and seawater is reliable (Tzeng et al., 2002). Thus, the salinity history of the eels may be reconstructed from the otolith $\mathrm{Sr} / \mathrm{Ca}$ ratios.

\subsection{Effects of salinity on growth rates and its implication}

Japanese Eel, A. japonica, have been described as facultatively catadromous fish (Tsukamoto and Arai, 2001).Thus, yellow stage eels are tolerant of differing salinities and can live in freshwater and seawater environments or migrate between these two habitats 
(Tzeng, 2003; Tzeng et al., 1997, 2002; Tsukamoto et al., 1998; Jessop et al., 2002, 2004; Cairns et al., 2004). However, the mean eel lengths and weights at the end of the experiment differed significantly among different salinities (Tables 1 and 2). Eel mean sizes were similar over a wide range of salinities. Growth in length was similar between $0-25$ psu but was higher at 25 psu than at 35 psu (Tables 1 and 2). Accordingly, the effects of salinity on the growth rates of the yellow eels cannot be neglected. Otolith $\mathrm{Sr} / \mathrm{Ca}$ ratios were negatively correlated with growth rate (Fig. 5), a phenomenon also found in the European Eels (Tzeng et al., 2000) and other species (Sadovy and Severin, 1992), but the mechanisms are not clear. They may be due to the trace elements $\mathrm{Sr}$ diluted by $\mathrm{Ca}$ when uptake of $\mathrm{Ca}$ increased with fast growth, or Sr has a strong affinity to organic substrate which increased in components when eels grow slow. Because $\mathrm{Ca}$ is a major element in otolith, fast growth will increase the uptake of $\mathrm{Ca}$ lead minor element $\mathrm{Sr}$ in otolith seems decreased relatively. Sr has a strong affinity to organic substrate; slowly growth will make them incorporate more in otolith.

\subsection{Do salinities or diets or both affect the $\mathrm{Sr} / \mathrm{Ca}$ ratios in otoliths?}

The elements in otoliths maybe absorbed through two pathways: from the water by ion exchange through the gills and from the diet through the digestive tract. Elements are then transported via the blood to the endolymph system of the inner ear, and finally deposited on the otolith surface by crystallization (Campana, 1999). Consequently, both water chemistry (including salinity) and diet have the potential to influence otolith element composition. We found that the slope and adjusted mean of the regressions of otolith $\mathrm{Sr} / \mathrm{Ca}$ ratio on salinity did not differ significantly between fish fed with tubifex, a formulated eel feed, and starvation (Fig. 2), even if the $\mathrm{Sr} / \mathrm{Ca}$ concentration ratios differed $4 \times$ between diets (Table $4 a, b)$. The partition coefficient $\left(D_{\mathrm{Sr}}\right)$ differed between diets. However, the $\mathrm{Sr} / \mathrm{Ca}$ ratio of the eel otoliths were all positively correlated with salinity irrespective of the fish diet fed. The elements $\mathrm{Sr}$ and $\mathrm{Ca}$ in otoliths of freshwater fish were mainly derived from water, accounting for $90 \%$ and $80 \%$ respectively (Simkiss, 1974; Farrell and Campana, 1996). Eel elvers reared in both freshwater and seawater with diets differing $4 \times$ in $\mathrm{Sr} / \mathrm{Ca}$ concentration ratios showed no significant difference in otolith $\mathrm{Sr} / \mathrm{Ca}$ ratios between diets (Table 5). Obviously, the dietary contribution to the elemental composition of the eel otolith was negligible.

\subsection{Effect of salinity on Dsr}

The partition coefficients $\left(D_{\mathrm{Sr}}\right)$ of the $\mathrm{Sr} / \mathrm{Ca}$ ratios between ambient water and both fish tissue and otolith all increased with salinity (Figs. 6-8). Thus, the $\mathrm{Sr} / \mathrm{Ca}$ ratio incorporated into otoliths was not constant among salinities although the $\mathrm{Sr} / \mathrm{Ca}$ ratio in seawater was constant (Fig. 1c). In addition, comparison of the regression slopes of $D_{\mathrm{Sr}}$ on salinity among water, tissue, and otolith indicated that the slopes were highest between otolith and fish tissue (0.0132), medium between water and otolith (0.0044-0.0065), and lowest between water and fish tissue $(0.0023-0.0024)$. The $D_{\mathrm{Sr}}$ not only changed with salinity but also among barriers. However, ANCOVA indicated that the differences in slopes and adjusted means of the regression lines between diets were not significant (Figs. 6 and 8), indicating that $D_{\mathrm{Sr}}$ were not influenced by diet.

Bath et al. (2000) found that $D_{\mathrm{Sr}}$ between ambient water and otoliths of marine fish were influenced by temperature; increasing from 0.182 at $20{ }^{\circ} \mathrm{C}$ to 0.205 at $25^{\circ} \mathrm{C}$. But this effects of temperature on $D_{\mathrm{Sr}}$ were not significant for fish scales (Wells et al., 2000), where the value was 0.16 . Elsdon and Gillanders (2003) found that the $D_{\mathrm{Sr}}$ in Black Bream, Acanthopagrus butcheri, decreased with increasing elemental concentrations of rearing water, thus increasing at lower $\mathrm{Sr} / \mathrm{Ca}$ ratios. The $D_{\mathrm{Sr}}$ of $\mathrm{Sr} / \mathrm{Ca}$ ratios for Trout, Oncorhyncus clarki lewisi, differed between otoliths and scales (Wells et al., 2003) while Kraus and Secor (2004) found similar phenomenon in perch, Morone americana. Martin et al. (2004) observed that $D_{\mathrm{Sr}}$ for Spot, Leiostomus xanthurus, differed with salinity and temperature. Zimmerman (2005) found that $D_{\mathrm{Sr}}$ differed with salinity and among 5 salmonid species. Thus, the $D_{\mathrm{Sr}}$ differ between fish species and tissues. Generally, $D_{\mathrm{Sr}}$ were higher in freshwater than in seawater but Vries et al. (2005) found that $D_{\mathrm{Sr}}$ in Black Bream were higher in brackish water than in seawater.

The incorporation of elements from ambient water to organism is a complicated physiological process. Different species have different regulation mechanisms and the uptake of elements differs between freshwater and seawater species in response to salinity. Marine fishes absorb elements largely through the intestinal walls and freshwater fishes through the calcium channels of the chloride cells in the gill (Campana, 1999; Katoh and Kaneko, 2002). A positive relation between salinity and otolith $\mathrm{Sr} / \mathrm{Ca}$ ratio in Japanese Eels and the absence of a dietary effect on $\mathrm{Sr} / \mathrm{Ca}$ ratio suggests that eel environmental histories can be reliably reconstructed from otolith $\mathrm{Sr} / \mathrm{Ca}$ ratio patterns. Further 
study on the salinity-dependent $D_{\mathrm{Sr}}$ and growth ratedependent otolith $\mathrm{Sr} / \mathrm{Ca}$ incorporation may permit more precise determination of habitat use by Japanese Eels from their otolith $\mathrm{Sr} / \mathrm{Ca}$ ratios.

\section{Acknowledgements}

This study was financially supported by the ROC National Science Council (NSC 94-2313-B002-070 awarded to Dr. WN Tzeng). The authors are grateful to Dr. Pung-Pung Hwang and Mr Fu-I Lu, Fish Physiological Ecology Laboratory, Institute of Cellular and Organismic Biology, Academia Sinica for helping AAS operation, Messrs Chun-Hung Chen and Jie-Teng He for fieldwork, Dr. David Cairns and Brian Jessop, Department of Fisheries and Oceans, Canada, and Dr. Y.S Han, Institute of Fisheries Science, National Taiwan University, Taiwan, ROC for reviewing the manuscript. [RH]

\section{References}

Arslan, Z., Secor, D.H., 2005. Analysis of trace transition elements and heavy metals in fish otoliths as tracers of habitat use by American eels in the Hudson river estuary. Estuaries 28 (3), 382-393.

Bath, G.E., Thorrold, S.R., Jones, C.M., Campana, S.E., McLaren, J.W., Lam, J.W.H., 2000. Strontium and barium uptake in aragonitic otoliths of marine fish. Geochim. Cosmochim. Acta 64 (10), 1705-1714.

Buckel, J.A., Sharack, B.L., Zdanowicz, V.S., 2004. Effect of diet on otolith composition in Pomatomus saltatrix, an estuarine piscivore. J. Fish Biol. 64, 1469-1484.

Campana, S.E., 1999. Chemistry and composition of fish otoliths: pathways, mechanisms, and applications. Mar. Ecol. Prog. Ser. 188, 263-297.

Chang, C.W., Lin, S.H., Iizuka, Y., Tzeng, W.N., 2004. Relationship between Sr:Ca ratios in otoliths of grey mullet Mugil cephalus and ambient salinity: validation, mechanisms, and applications. Zool. Stud. 43 (1), 74-85.

Cheng, P.W., Tzeng, W.N., 1996. Timing of metamorphosis and estuarine arrival across the dispersal range of the Japanese Eel Anguilla japonica. Mar. Ecol. Prog. Ser. 131, 87-96.

Cairns, D.K., Shiao, J.C., Iizuka, Y., Tzeng, W.N., MacPherson, C.D., 2004. Movement patterns of American eels in an impounded watercourse, as indicated by otolith microchemistry. N. Am. J. Fish Manag. 24, 452-458.

Degens, E.T., Deuser, W.G., Haedrich, R.L., 1969. Molecular structure and composition of fish otoliths. Mar. Biol. 2, 105-113.

Daverat, F., Limburg, K.E., Thibanlt, I., Shiao, J.C., Dodson, J.J., Caron, F., Tzeng, W.N., Iizuka, Y., Wickstrom, H., 2006. Phenotypic plasticity of habitat use by three temperate eel species, Anguilla anguilla, A. japonica and A. rostrata. Mar. Ecol. Prog. Ser. 308, 231-241.

Elsdon, T.S., Gillanders, B.M., 2003. Relationship between water and otolith elemental concentrations in juvenile black bream Acanthopagrus butcheri. Mar. Ecol. Prog. Ser. 260, 263-272.

Farag, A.M., Suedkamp, M.J., Meyer, J.S., Barrows, R., Woodward, D.F., 2000. Distribution of metals during digestion by cutthroat trout fed benthic invertebrates contaminated in the Clark Fork River, Montana and the Coeur d'Alene River, Idaho, U.S. A., and fed artificially contaminated Artemia. J. Fish Biol. 56, 173-190.

Farrell, J., Campana, S.E., 1996. Regulation of calcium and strontium deposition on the otoliths of juvenile tilapia, Oreochromis niloticus. Comp. Biochem. Physiol. 115A, 103-109.

Gallahar, N.K., Kingsford, M.J., 1996. Factors influencing $\mathrm{Sr} / \mathrm{Ca}$ ratios in otoliths of Girella elevata: an experimental investigation. J. Fish Biol. 48, 174-186.

Gauldie, R.W., Nelson, D.G.A., 1988. Aragonite twinning and neuroprotein secretion are the cause of daily growth rings in fish otolith. Comp. Biochem. Physiol. 90A, 501-509.

Hoff, G.R., Fuiman, L.A., 1995. Environmentally induced variation in elemental composition of red drum (Sciaenops ocellatus) otoliths. Bull. Mar. Sci. 56 (2), 578-591.

Howland, K.L., Tonn, W.M., Babaluk, J.A., Tallman, R.F., 2001. Identification of freshwater and anadromous inconnu in the Mackenzie River system by analysis of otolith strontium. Trans. Am. Fish. Soc. 130 (5), 725-741.

Jessop, B.M., Shiao, J.C., Iizuka, Y., Tzeng, W.N., 2002. Migratory behaviour and habitat use by American eels Anguilla rostrata as revealed by otolith microchemistry. Mar. Ecol. Prog. Ser. 233, 217-229.

Jessop, B.M., Shiao, J.C., Iizuka, Y., Tzeng, W.N., 2004. Variation in the annual growth, by sex and migration history, of silver American eels Anguilla rostrata. Mar. Ecol. Prog. Ser. 272, 231-244.

Kalish, J.M., 1990. Use of otolith microchemistry to distinguish the progeny of sympatric anadromous and non-anadromous salmonids. Fish Bull. 88, 657-666.

Katoh, F., Kaneko, T., 2002. Effects of environmental $\mathrm{Ca}^{2+}$ levels on branchial chloride cell morphology in freshwater-adapted killifish Fundulus heteroclitus. Fish Sci. 68, 347-355.

Kawakami, Y., Mochioka, N., Morishita, K., Tajima, T., Nakagawa, H., Toh, H., Nakazono, A., 1998. Factors influencing otolith strontium calcium ratios in Anguilla japonica elvers. Environ. Biol. Fish 52, 299-303.

Kotake, A., Arai, T., Ohji, M., Yamane, S., Miyazaki, N., Tsukamoto, K., 2004. Application of otolith microchemistry to estimate the migratory history of Japanese Eel Anguilla japonica on the Sanriku Coast of Japan. J. Appl. Ichthyol. 20, 150-153.

Kraus, R.T., Secor, D.H., 2004. Incorporation of strontium into otoliths of an estuarine fish. J. Exp. Mar. Biol. Ecol. 302, 85-106.

Liao, I.C., Kuo, C.L., Tzeng, W.N., Hwang, S.T., Wu, C.L., Wang, C.H., Wang, Y.T., 1996. The first time of leptocephali of Japanese Eel Anguilla japonica collected by Taiwanese researchers. J. Taiwan Fish Res. 4, 107-116.

Liao, I.C., Liau, S.G., Tzeng, W.N., Kuo, C.L., 1999. Investigation on Anguilla japonica leptocephali by Fisheries Researcher 1. In studies on the life cycle of eel. In: Aida, K., Tsukamoto, K. (Eds.), Kaiyo Monthly, Special Issue, vol. 18, pp. 27-33.

Limburg, K.E., 1995. Otolith strontium traces environmental history of subyearing American shad Alosa sapidissima. Mar. Ecol. Prog. Ser. $119,25-35$.

Limburg, K.E., Landergren, P., Westin, L., Elfman, M., Kristiansson, P., 2001. Flexible modes of anadromy in Baltic Sea trout: making the most of marginal spawning streams. J. Fish Biol. 59, 682-695.

Martin, G.B., Thorrold, S.R., Jones, C.M., 2004. Temperature and salinity effects on strontium incorporation in otoliths of larval spot (Leiostomus xanthurus). Can. J. Fish Aquat. Sci. 61, 34-42. 
Milton, D.A., Chenery, S.R., 2001. Sources and uptake of trace metals in otolith of juvenile barramundi (Lates calcarifer). J. Exp. Mar. Biol. Ecol. 264, 47-65.

Ni, I.H., Wang, W.X., Tam, Y.K., 2000. Transfer of Cd, Cr and Zn from zooplankton prey to mudskipper Periophthalmus cantonensis and glassy Ambassis urotaenia fishes. Mar. Ecol. Pro. Ser. 194, 203-210.

Radtke, R.L., Kinzie III, R.A., 1996. Evidence of a marine larval stage in endemic Hawaiian stream gobies isolated from high-elevation locations. Trans. Am. Fish Soc. 125, 613-621.

Sadovy, Y., Severin, K.P., 1992. Trace elements in biogenic aragonite: correlation of body growth rate and strontium levels in the otoliths of the white grunt, Haemulon plumieri (Pisces: Haemulidae). Bull. Mar. Sci. 50, 237-257.

Secor, D.H., Piccoli, P.M., 1996. Age-and sex-dependent migrations of striped bass in the Hudson River as determined by chemical microanalysis of otoliths. Estuaries 19 (4), 778-793.

Secor, D.H., Rooker, J.R., 2000. Is otolith strontium a useful scalar of life cycles in estuarine fishes? Fisheries Research 46, 359-371.

Secor, D.H., Henderson-Arzapalo, A., Piccoli, P.M., 1995. Can otolith microchemistry chart patterns of migration and habitat utilization in anadromous fishes? J. Exp. Mar. Biol. Ecol. 192, 15-33.

Secor, D.H., Ota, T., Tanaka, M., 1998. Use of otolith microanalysis to determine estuarine migrations of Ariake Sea Japanese sea bass Lateolabrax japonicus. Fish. Sci. 64, 740-743.

Shen, K.N., Tzeng, W.N., 2002. Formation of a metamorphosis check in otoliths of the amphidromous goby Sicyopterus japonicus. Mar. Ecol. Prog. Ser. 228, 205-211.

Shen, K.N., Lee, Y.C., Tzeng, W.N., 1998. Use of otolith microchemistry to investigate the life history pattern of gobies in a Taiwanese stream. Zool. Stud. 37 (4), 322-329.

Simkiss, K., 1974. Calcium metabolism of fish in relation to ageing. In: Bagenal, T.B. (Ed.), The Ageing of Fish. Unwin Brothers Ltd, Old Woking, pp. 1-12.

Tsukamoto, K., 1992. Discovery of the spawning area for Japanese Eel. Nature 356, 789-791.

Tsukamoto, K., Arai, T., 2001. Facultative catadromy of the eel Anguilla japonica between freshwater and seawater habitats. Mar. Ecol. Prog. Ser. 220, 265-276.

Tsukamoto, K., Nakai, I., Tesch, W.V., 1998. Do all freshwater eels migrate? Nature 396, 635-636.
Tzeng, W.N., 1996. Effects of salinity and ontogenetic movements on strontium:calcium ratios in the otoliths of the Japanese Eel, Anguilla japonica Temminck and Schlegel. J. Exp. Mar. Biol. Ecol. 199, 111-122.

Tzeng, W.N., 2003. The processes of onshore migration of the Japanese Eel Anguilla japonica as revealed by otolith microstructure. Eel Biology 181-190.

Tzeng, W.N., Tsai, Y.C., 1994. Changes in otolith microchemistry of the Japanese Eel, Anguilla japonica, during its migration from the ocean to the rivers of Taiwan. J. Fish Biol. 45, 671-683.

Tzeng, W.N., Severin, K.P., Wickström, H., 1997. Use of otolith microchemistry to investigate the environmental history of European eel Anguilla anguilla. Mar. Ecol. Prog. Ser. 149, 73-81.

Tzeng, W.N., Wang, C.H., Wickström, H., Reizenstein, M., 2000. Occurrence of the semi-catadromous European eel Anguilla anguilla (L.) in Baltic Sea. Mar. Biol. 137, 93-98.

Tzeng, W.N., Shiao, J.C., Iizuka, Y., 2002. Use of otolith Sr:Ca ratios to study the riverine migratory behaviours of Japanese Eel Anguilla japonica. Mar. Ecol. Prog. Ser. 245, 213-221.

Vries, M.C., Gillander, B.M., Elsdon, T.S., 2005. Facilitation of barium uptake into fish otoliths: influence of strontium concentration and salinity. Geochimica et Cosmochimica Acta 69 (16), 4061-4072.

Walther, B.D., Thorrold, S.R., 2006. Water, not food, contributes the majority of strontium and barium deposited in the otoliths of a marine fish. Mar. Ecol. Prog. Ser. 311, 125-130.

Wells, B.K., Bath, G.E., Thorrold, S.R., Jones, C.M., 2000. Incorporation of strontium, cadmium, and barium in juvenile spot (Leiostomus xanthurus) scales reflects water chemistry. Can. J. Fish. Aquat. Sci. 57, 2122-2129.

Wells, B.K., Rieman, B.E., Clayton, J.L., Horan, D.L., Jones, C.M., 2003. Relationship between water, otolith, and scales chemistries of Westslope Cutthroat Trout from the Coeur d' Alene River, Idaho: the potential application of hard-part chemistry to describe movements in freshwater. Transactions of the American Fisheries Society 132, 409-424.

Zimmerman, C.E., 2005. Relationship of otolith strontium-to-calcium ratios and salinity: experimental validation for juvenile salmonids. Can. J. Fish Aquat. Sci. 62, 88-97. 